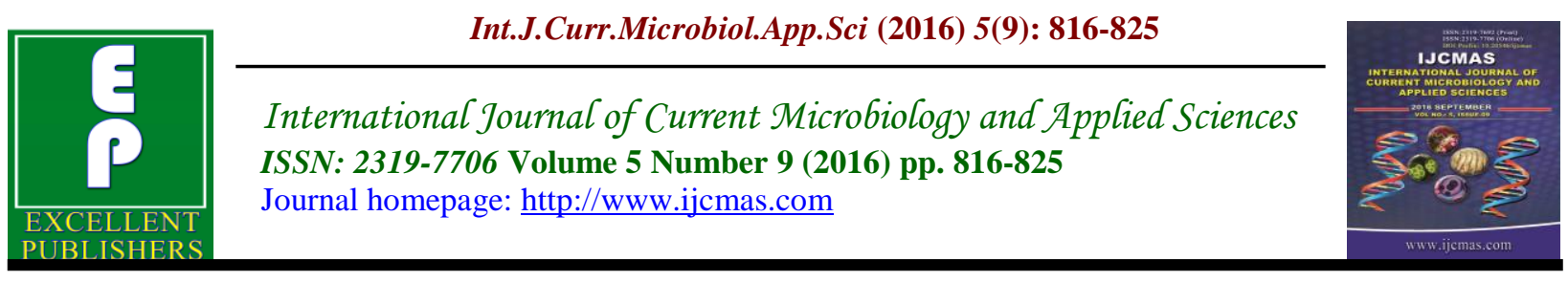

Original Research Article

http://dx.doi.org/10.20546/ijcmas.2016.509.092

\title{
Analysis of Bacterial Community in the Rhizosphere of Rice subjected to Heavy Metal Pollution
}

\author{
Ding Zili ${ }^{1,2}$, Wu Jinping ${ }^{2}$, Jiao Chunhai ${ }^{2}$ and Cao Cougui ${ }^{1}{ }^{*}$ \\ ${ }^{1}$ College of Plant Science and Technology, Huazhong Agricultural University, \\ Wuhan43070, China \\ ${ }^{2}$ Hubei Academy of Agricultural Sciences, Wuhan430064, China \\ *Corresponding author
}

\section{Keywords}

Soil pollution; Heavy metals; Rhizosphere; PCR-DGGE; Microbial community.

\section{Article Info}

Accepted:

15 August 2016 Available Online: 10 September 2016

\section{A B S T R A C T}

PCR amplification of 16S rRNA genes and denaturing gradient gel electrophoresis (DGGE) analysis were used to examine the compositions and dynamics of bacterial communities in the rhizosphere of rice subjected to heavy metal pollution. DGGE showed many common bands under conditions of $\mathrm{Cd}$ and $\mathrm{Cr}$ pollution, suggesting the presence of similar of bacterial communities. Principal component analysis showed different microbial community structure changes during the study period, for $\mathrm{Cd}$ and $\mathrm{Cr}$ pollution respectively. Major bands of DGGE patterns were sequenced. Phylogenetic analysis indicated that the majority of the sequences obtained were affiliated with members of Acidobacteria (18.75\%), Myxococcales $(12.50 \%)$, Gemmatimonas $(12.50 \%)$, and Thiothrix $(9.38 \%)$. When the rice plants reached the heading stage, the relative abundance of members of Gemmatimon as increased with $\mathrm{Cd}$ concentration, while abundance of members of Gallionellaceae increased with $\mathrm{Cr}$ concentration. At the maturation stage, the relative abundance of members of Chlorobiales increased with $\mathrm{Cd}$ concentration. These results illuminate the effect on diversity of heavy metal pollution in soil. Further study of combinations of other environmental parameters will clarify heavy metal effects on the activity of microbial communities in rice paddy fields.

\section{Introduction}

Heavy metal pollution can persist for a long time in soil, potentially migrating to crops and entering the food chain, leading to public health concerns. As one of the world's main planted crops, rice plays a huge part in the migration of heavy metals into the food chain. In recent years, heavy metal pollution has been widely reported in the arable fields of South China, due to the rapid development of mining activities, the metallurgical industry, sewage irrigation, and the application of pesticides and fertilizers (Chen et al., 2014; Gong et al., 2009; Zeng et al., 2013a). Heavy metal pollution in soil has been paid extensive attention worldwide, especially in countries undergoing rapid industrialization and urbanization. Human-spread metals 
including lead, mercury, and copper have been detected in snow samples from both Greenland and Antarctica, in areas remote from human habitation (Lobinski et al., 1994; Van de Velde et al., 2005). The most common heavy metal contaminants include mercury, cadmium, lead, chromium, arsenic, zinc, copper, nickel, and cobalt, each of which is potentially toxic to humans (Tang et al., 2014; Xu et al., 2012). While soil is a fundamentally important biome that is crucial for terrestrial life, it also acts as a reservoir for toxic substances that are deleterious to soil microbiota, the food chain, and human health (Akcay et al., 2003; Khan et al., 2010; Wang et al., 2007).

In topsoil ecosystems, bacteria and fungi generally constitute more than $90 \%$ of the total soil microbial biomass, and are the main regulators of soil organic matter dynamics and nutrient availability (Chen et al., 2014). Soil microorganisms play an important role in energy flow, nutrient cycling, and organic matter turnover (Eguchi et al., 2001; Frische and Hoper, 2003; Sabater et al., 2003; Tonkovic, 1998). They are sensitive to toxic substances such as heavy metals, which affect their community structure and function.

This paper examines the effect of heavy metal pollution on microbial community structure indifferent concentrations and different heavy metal pollution, using PCR and denaturing gradient gel electrophoresis (DGGE) to describe the community and its changes in response to environmental variation. Relationships between the rhizosphere microbial community and environmental parameters are described. This study is intended to highlight the effects of heavy metal pollution, particularly its toxicity to soil microorganism near metallurgical plant districts in China.

\section{Materials and Methods}

\section{Natural profile of the study site}

The study was conducted at the experimental field station of Huazhong Agricultural University in Hubei Province, China $\left(30^{\circ} \mathrm{N}, 114^{\circ} \mathrm{E}, 50 \mathrm{~m}\right.$ a.s.1.), where the average temperature is between $15.8^{\circ} \mathrm{C}$ and $17.5^{\circ} \mathrm{C}$. The maximum and minimum recorded temperatures are $44.5{ }^{\circ} \mathrm{C}$ and -18 ${ }^{\circ} \mathrm{C}$, respectively. The average annual precipitation is $1,269 \mathrm{~mm}$, and the climate is sub-tropical monsoon.

\section{Experimental design}

Clay loam surface $(0-20 \quad \mathrm{~cm})$ soil undergoing heavy metal treatment was sampled from the experimental rice paddy field at Huazhong Agricultural University in early March 2014. The soil was air-dried, ground and passed through mesh sieves. Six-kilogram samples of soil were collected in cylindrical plastic containers (each with an upper diameter of $29 \mathrm{~cm}$ and a height of $30 \mathrm{~cm}$ ). Solutions of $\mathrm{CdCl}_{2}$ and $\mathrm{K}_{2} \mathrm{Cr}_{2} \mathrm{O}_{7}$ were added to the containers. The final $\mathrm{Cd}^{2+}$ concentrations were $10 \mathrm{mg} / \mathrm{kg}(\mathrm{Cd} \mathrm{1),} 20$ $\mathrm{mg} / \mathrm{kg}(\mathrm{Cd} \mathrm{2})$, and $50 \mathrm{mg} / \mathrm{kg}(\mathrm{Cd} \mathrm{3})$, and the final $\mathrm{Cr}^{6+}$ concentrations were $100 \mathrm{mg} / \mathrm{kg}(\mathrm{Cr}$ 1), $400 \mathrm{mg} / \mathrm{kg}$ (Cr 2), and $700 \mathrm{mg} / \mathrm{kg}$ (Cr 3). The control treatment was water without heavy metal. Containers were arranged according to a randomized block design with seven treatments. Each treatment had eight replicates. Before sowing seeds, 56 randomly selected containers were filled with water to cover the soil by $2-3 \mathrm{~cm}$ for one month to balance the concentrations of $\mathrm{Cd}^{2+}$ and $\mathrm{Cr}^{6+}$. Japonica rice (Wuyujing 3) was chosen as the experimental plant, because it shows different characteristics with heavy metal treatments. Seeds were sown after 5 days of germination. 
Compound fertilizer ( $1 \mathrm{~g}$ ) was applied at the three-leaf stage and the spike differentiation stage. Throughout preparation, sowing, germination and early seedling growth, 2-3 $\mathrm{cm}$ of water covered the soil. Initial characteristics of the soil samples were as follows: soil organic matter (SOM), $2.19 \pm$ $0.07 \%$; available nitrogen, $51.1 \pm 1.06 \mathrm{mg}$ $\mathrm{kg}^{-1}$; available phosphorus, $21.3 \pm 2.11 \mathrm{mg}$ $\mathrm{kg}^{-1}$; available potassium, $74.0 \pm 3.15 \mathrm{mg}$ $\mathrm{kg}^{-1}$; total nitrogen, $1.14 \pm 1.01 \mathrm{mg} \mathrm{g}^{-1}$; total phosphorus $0.42 \pm 1.21 \mathrm{mg} \mathrm{g}^{-1}$; total $\mathrm{Cr}$, $80.4 \pm 1.15 \mathrm{mg} \mathrm{kg}^{-1}$; total $\mathrm{Pb}, 25.2 \pm 1.54 \mathrm{mg}$ $\mathrm{kg}^{-1}$; and total $\mathrm{Cd}, 0.18 \pm 0.05 \mathrm{mg} \mathrm{kg}^{-1}$.

Sampling of the rhizosphere of the rice plants was conducted as follows: eight soil samples per treatment were collected at random from the rice rhizosphere, and were combined. Loose soil was removed from the roots, and the remaining soil that adhered strongly to the roots was recovered as rhizosphere soil. The sampling took place at the heading stage (August 6) and maturing stage (September 18) in 2014. Part of the soil was stored at $4{ }^{\circ} \mathrm{C}$ for subsequent microbial abundance determination, another part of the soil was stored at $-80{ }^{\circ} \mathrm{C}$ for soil microbiological analysis, and the remainder was air-dried, ground and passed through 1$\mathrm{mm}$ and 2-mm mesh sieves for chemical analysis.

\section{DNA extraction}

Total community DNA was isolated from soil samples $(0.5 \mathrm{~g})$ using the E.Z.N.A ${ }^{\mathrm{TM}}$ Soil DNA kit (Omega Bio-Tek, Inc., Norcross, GA, USA) according to the manufacturer's instructions. DNA was eluted with $30 \mu \mathrm{L}$ of elution buffer and stored at $-20^{\circ} \mathrm{C}$. DNA concentrations ranged from 125 to $280 \mathrm{ng} / \mu \mathrm{L}$.DNA concentration was measured by NanoDrop

\section{PCR-DGGE profiling}

The $\mathrm{V} 3$ region of the $16 \mathrm{~S}$ rRNA gene was amplified from the DNA samples using touchdown PCR (Van et al., 1999). 16S rRNA genes were amplified using the primers 16SB-1/16SB-2; Primer sequences were as follows: 16SB-1: 5'-CGCCCGC CGCGCGCGGCGGGCGGGGCGGGGGC ACGGGGGGCCTACGGGAGGCAGCAG3'; 16SB-2: 5'-ATTACCG CGGCTGC TGG-3'. The reaction mixture $(25.0 \mu \mathrm{L})$ contained $1.0 \mu \mathrm{L}$ of DNA template, $12.5 \mu \mathrm{L}$ Takara LA-Taq Mix (TaKaRa Biotechnology Co., Ltd, Dalian, China) and $1.0 \mu \mathrm{L}$ of each primer. PCR amplification was as follows: an initial denaturing step of 5 min at $95{ }^{\circ} \mathrm{C}$ followed by 20 cycles of 1 min at $94{ }^{\circ} \mathrm{C}, 1 \mathrm{~min}$ of annealing at 65-55 ${ }^{\circ} \mathrm{C}$, and a 3 min extension at $72{ }^{\circ} \mathrm{C}$, followed by 10 cycles of $1 \mathrm{~min}$ at $94{ }^{\circ} \mathrm{C}, 1 \mathrm{~min}$ at 55 ${ }^{\circ} \mathrm{C}, 3 \mathrm{~min}$ at $72{ }^{\circ} \mathrm{C}$, a final extension step at $72{ }^{\circ} \mathrm{C}$ for $10 \mathrm{~min}$. PCR products were checked by electrophoresis on $1 \%(\mathrm{w} / \mathrm{v})$ agarose gels. DGGE analysis was performed with the D Code Universal Mutation Detection System (Bio-Rad, Hercules, CA, USA). PCR products $(20 \mu \mathrm{L})$ of each sample were loaded onto an $8 \%(\mathrm{w} / \mathrm{v})$ acrylamide gel with a 40-60\% denaturing gradient (urea and formamide) as described by Huang et al., (2013). The DGGE profile was analyzed with Quantity One software (Bio-Rad).

\section{Specific amplification of particular DGGE bands}

DNA fragments forming particular DGGE bands were amplified using specific PCR primers. The primers were as follows: 16SS1: 5'-AGAGTTTGATCATGGCTCAG-3'; 16SS-2: 5'-TAGGGTTACCTTGTT ACG ACTT-3'. DNA fragments were cloned in Escherichia coli DH5 $\alpha$ using the pMD19-T Vector System (TaKaRa Biotechnology Co., Ltd, Dalian, China) according to the manufacturer's instructions. 


\section{Sequence analysis}

The 16S rRNA partial sequences obtained in this study have been deposited in the NCBI. Sequences of the DGGE bands were also compared to those present in the databases using BLAST search program at the NCBI web site. Sequences were aligned using ClustalX (1.81) as implemented. The phylogenetic tree of the aligned sequences was constructed with 1,000-fold bootstrap analysis by using the neighborjoining method with the MEGA5.1 (Molecular Evolutionary Genetics Analysis, MEGA) software (Kumar, 2008).

\section{Statistical analysis}

Digitized DGGE images were analyzed with the Quantity One image analysis software (version 4.0, Bio-Rad, USA).This software identifies the bands occupying the same position in different lanes of a gel. The diversity index of the soil actinomycetes communitieswas evaluated using the Shannon-Wiener index (H) (Hill et al., 2003).

Cluster analysis was performed using the unweighted pair group method with arithmetic mean. The band data were subjected to principal component analysis (PCA) using the Statistical Package for the Social Sciences version 16.0 for Windows (SPSS Incorporated 2007). The principal components were then extracted from the correlation matrix. The standardized data were then projected onto the principal axes, plotted in two dimensions, and examined for clustering behavior (Daniela et al., 2012).

\section{Nucleotide sequence accession numbers}

The sequence of each clone was determined and all sequences were deposited into the GenBank database with the accession numbers KR997935.1 through KR997966.1

\section{Results and Discussion}

Community structure of bacteria in the rhizosphere of rice under pollution of heavy metals

DGGE profiles of the V3 hypervariable region of $16 \mathrm{~S}$ rDNA genes from rice rhizosphere bacteria are shown in Table 1 . Soil samples were extracted at seedling heading and maturation stages. DGGE band numbers, and the Shannon diversity index were significantly higher in the heading stage than the mature stage. Each of the distinguishable bands in the DGGE separation pattern represents an individual bacterial species (Luca et al., 2002), so the species diversity of rhizosphere bacteria decreased as the rice grew. Band numbers and diversity were higher in the samples treated with different concentrations of cadmium, than in those treated with chromium, suggesting that the effects of cadmium were smaller than those of chromium. Under the heavy metal treatments, species diversity improved at the heading stage, which suggests that the rhizosphere bacteria were initially able to adapt to the heavy metal pollution. However, species diversity decreased at the mature stage, suggesting that some bacterial populations were damaged by or unable to adapt to sustained exposure to heavy metals.

Principal component analysis (PCA) on bacterial diversity data is shown in Figure 1, showing $57.24 \%$ of the variance in the data is explained by principal component 1 , and $27.98 \%$ by principal component 2 . Discrete distances were larger during heading and maturation stages with heavy metal pollution, which suggests that the rhizosphere bacterial community changed with prolonged exposure to heavy metal pollution. Discrete distances were largest for the $700 \mathrm{mg} / \mathrm{kg}$ chromium treatment, among 
heavy metal treatments, suggesting it had a greater influence on the rhizosphere bacterial community than other treatments.

\section{Sequence and phylogenetic analysis}

DGGE profiles differed among treatments and among sampling times, indicating the fluctuation of the microbial community structure in response to heavy metal pollution (Figure 2). Bands differed in intensity, indicating different population densities of different species. Thirty-two representative bands were excised and sequenced. Inferred homologies to known sequences in the NCBI database, based on BLAST results, ranged in similarity from 98 $\%$ to $100 \%$. Phylogenetic analysis revealed that the bacterial community was separated into two major groups (Figure 3). As shown in figures 2 and 3 , in the heading stage, the relative abundance of members of Gemmatimonas increased with $\mathrm{Cd}$ concentration relative to controls; and likewise the relative abundance of members of Gallionellaceae increased with $\mathrm{Cr}$ concentration relative to controls. In the maturation stage, the relative abundance of members of Chlorobiales increased with $\mathrm{Cd}$ concentration, relative to controls. The bacterial community in the rhizosphere is usually dynamic and our results show that it can be strongly affected by heavy metal pollution.

Metal pollution caused changes in the relative abundances of specific bacterial higher taxa, including Acidobacteria, Actinobacteria, Bacteroidetes, Chloroflexi, Firmicutes, Planctomycetes and Proteobacteria (Hamed et al.,, 2015). As shown in Figure 4, higher taxonomic affiliations of excised DGGE bands included Acidobacteria (18.75 \%), Myxococcales (12.50\%), Gemmatimonas (12.50\%), Thiothrix (9.38 \%), Firmicutes (6.25\%), Chlorobiales $(6.25 \%)$, Proteobacterium (6.25 \%), Gallionellaceae (6.25 \%), Bacteroidales (3.13\%), Caulobacter (3.13 $\%)$, Chloroflexi (3.13\%), Denitratisoma (3.13\%), Ferribacterium (3.13\%), Agrobacterium $(3.13 \%)$ and Clostridium $(3.13 \%)$.

Table.1

\begin{tabular}{llll}
\hline Sampling period & Treatments & Band numbers & Shannon-index \\
\hline Heading stage & Cd1 & $29 \pm 0.5 \mathrm{a}$ & $-3.2686 \pm 0.021 \mathrm{a}$ \\
& $\mathrm{Cd} 2$ & $29 \pm 1.5 \mathrm{a}$ & $-3.2762 \pm 0.054 \mathrm{a}$ \\
& $\mathrm{Cd} 3$ & $28 \pm 2.5 \mathrm{ab}$ & $-3.2550 \pm 0.098 \mathrm{a}$ \\
& $\mathrm{Cr} 1$ & $28 \pm 0.5 \mathrm{ab}$ & $-3.2452 \pm 0.019 \mathrm{a}$ \\
& $\mathrm{Cr} 2$ & $26 \pm 2.0 \mathrm{bc}$ & $-3.1841 \pm 0.100 \mathrm{abc}$ \\
& $\mathrm{Cr} 3$ & $26 \pm 0.5 \mathrm{abc}$ & $-3.2239 \pm 0.026 \mathrm{ab}$ \\
Maturation stage & Control & $26 \pm 1.0 \mathrm{bc}$ & $-3.2044 \pm 0.044 \mathrm{ab}$ \\
& $\mathrm{Cd} 1$ & $23 \pm 2.0 \mathrm{de}$ & $-3.0228 \pm 0.031 \mathrm{de}$ \\
& $\mathrm{Cd} 2$ & $25 \pm 3.0 \mathrm{~cd}$ & $-3.0850 \pm 0.048 \mathrm{~cd}$ \\
& $\mathrm{Cd} 3$ & $25 \pm 1.0 \mathrm{~cd}$ & $-3.1258 \pm 0.111 \mathrm{bcd}$ \\
& $\mathrm{Cr} 1$ & $22 \pm 0.5 \mathrm{e}$ & $-3.0827 \pm 0.020 \mathrm{~cd}$ \\
& $\mathrm{Cr} 2$ & $22 \pm 0.5 \mathrm{e}$ & $-3.0782 \pm 0.026 \mathrm{de}$ \\
& $\mathrm{Cr} 3$ & $22 \pm 0.0 \mathrm{e}$ & $-2.9759 \pm 0.077 \mathrm{e}$ \\
& $\mathrm{Control}$ & $25 \pm 1.0 \mathrm{~cd}$ & $-3.1868 \pm 0.076 \mathrm{bcd}$ \\
\hline
\end{tabular}


Fig.1 Principal component analysis of changes in bacterial diversity in the rhizophere of rice subjected to heavy metal pollution.

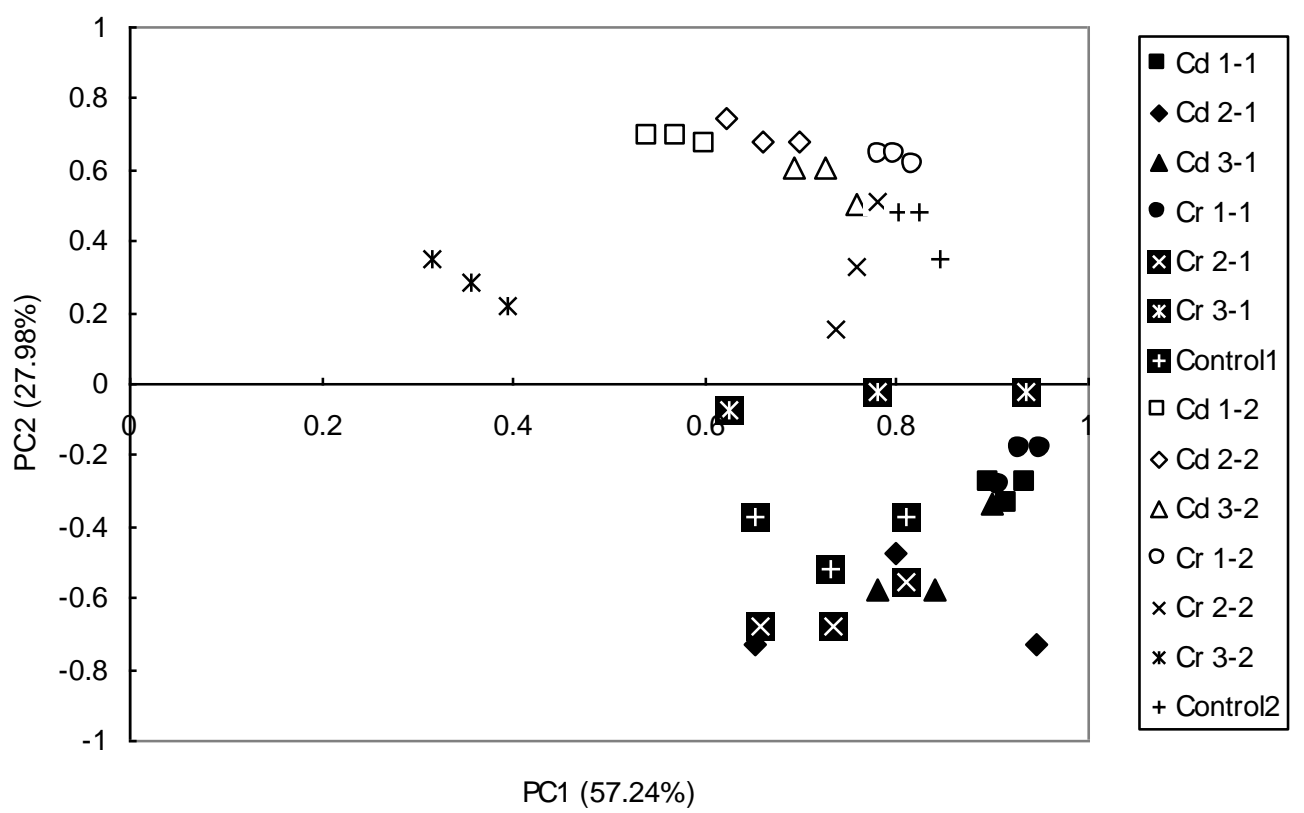

Fig.2 DGGE fingerprint profiles obtained with primers targeting the V3 region of $16 \mathrm{~S}$ rRNA, run in a denaturing 30-55\% gradient gel. Numbered bands correspond to the clones in Fig. 3. A:

Heading stage, B: Maturation stage.
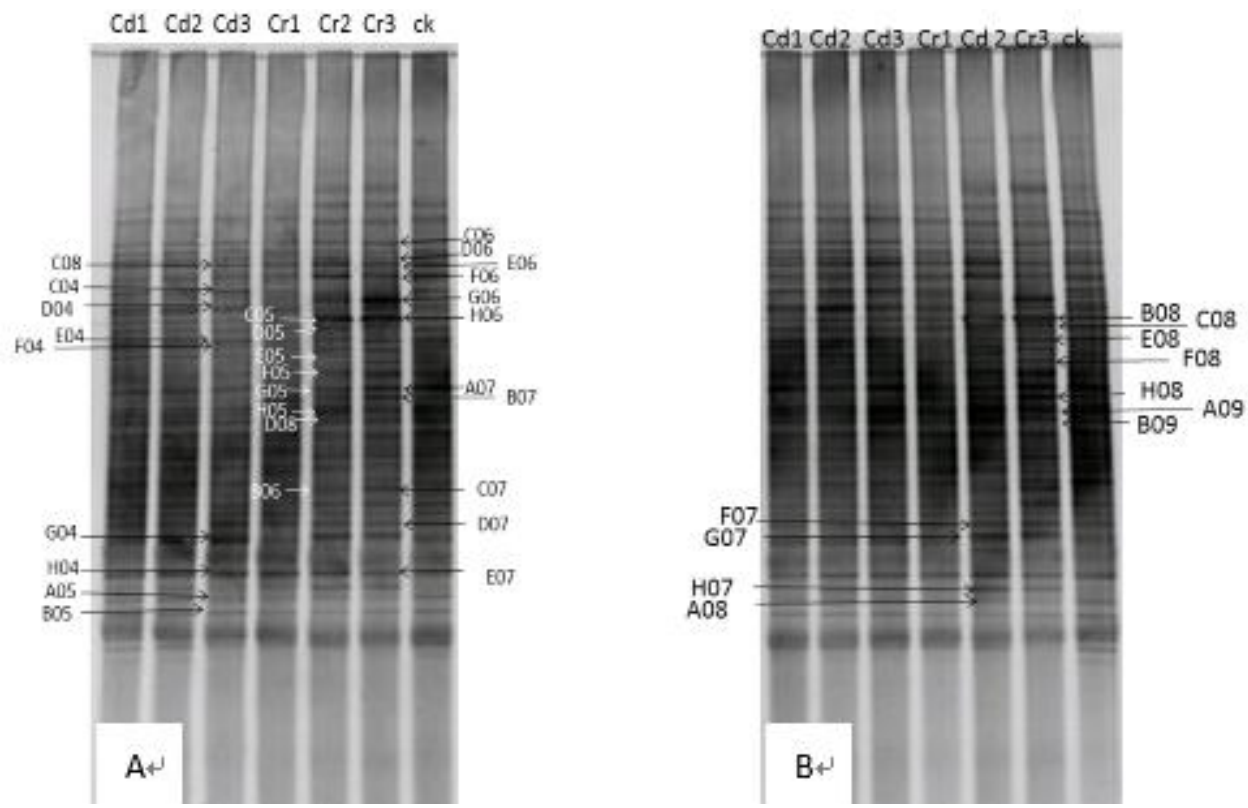
Fig.3 Neighbor-joining phylogenetic tree of V3 region 16S rRNA sequences, showing the relationship between the sequences retrieved from DGGE bands.

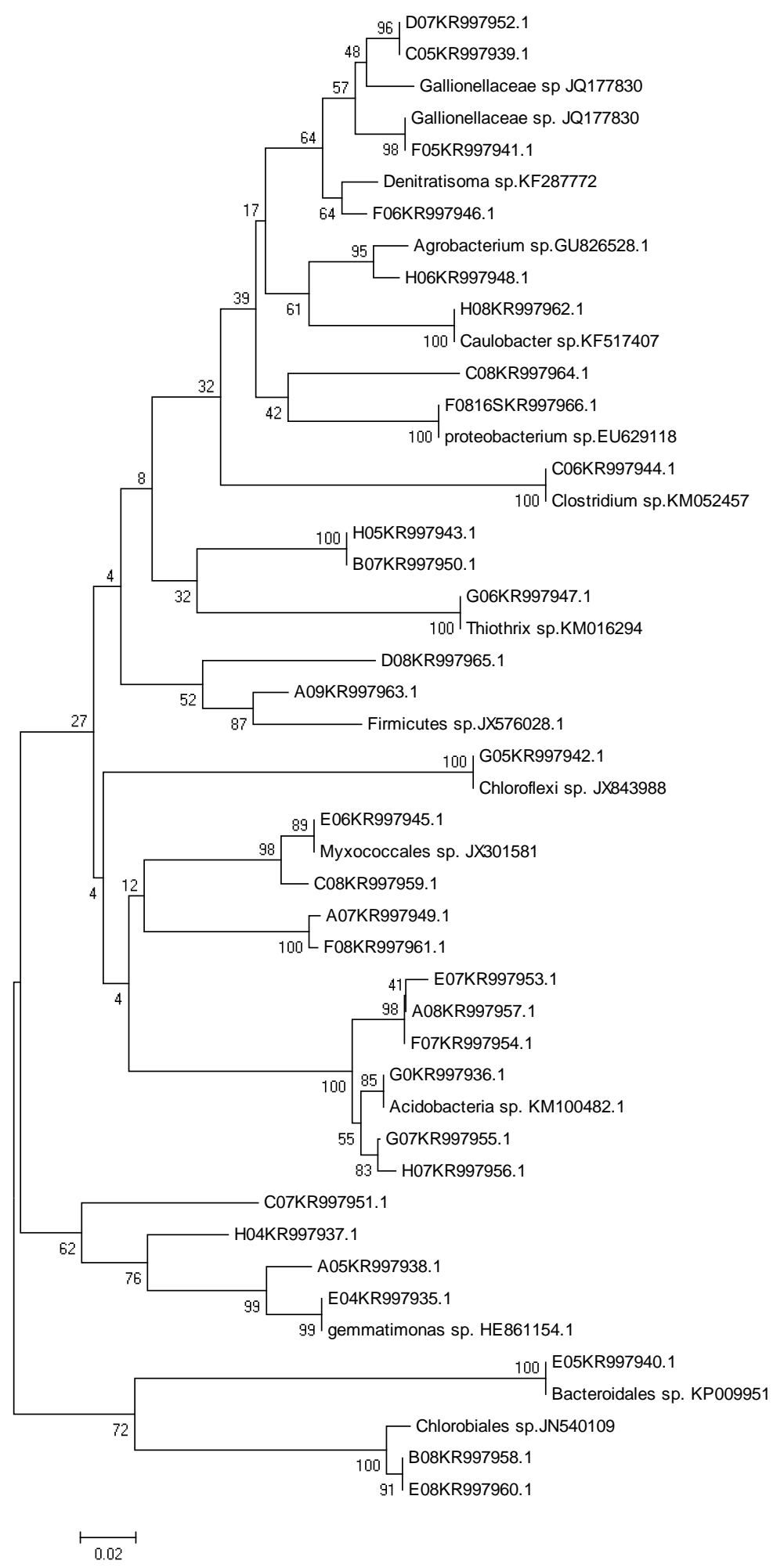


Fig.4 Taxonomic affiliations of the most-represented bacteria in the rhizosphere of rice subjected to heavy metal pollution.

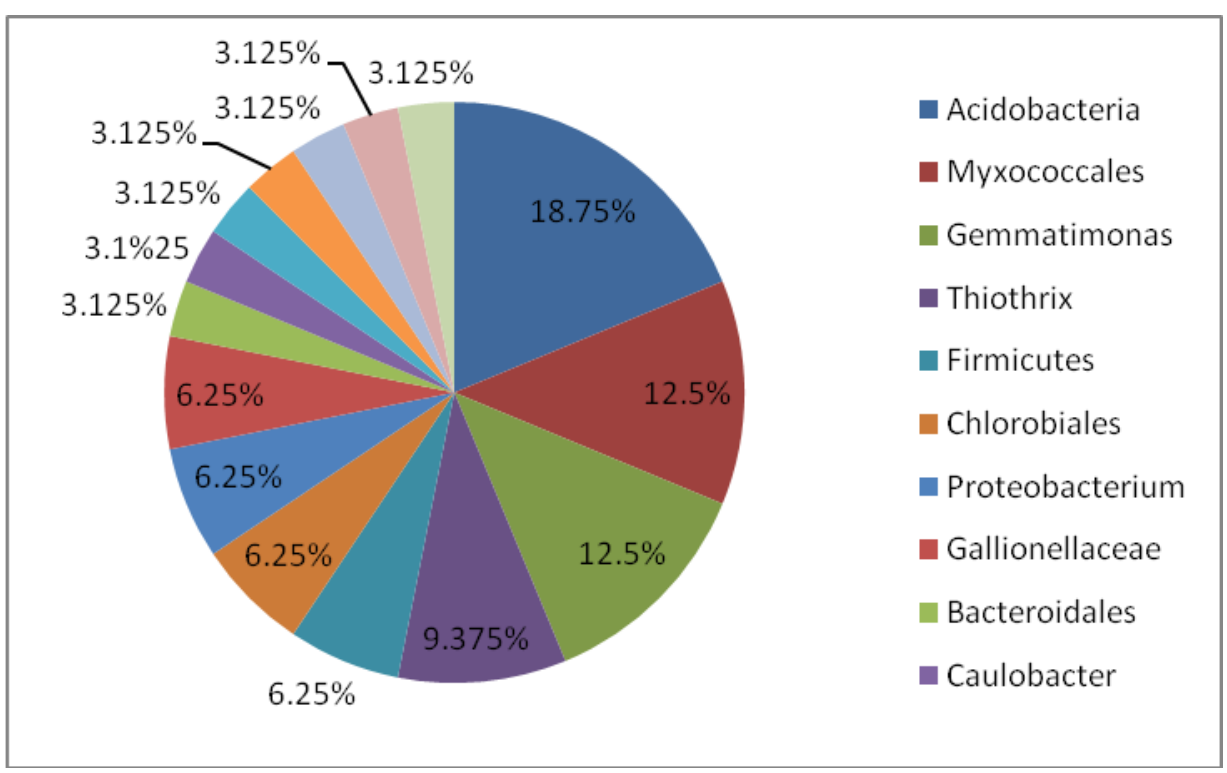

In conclusion, agricultural land contamination with heavy metals is an increasing problem globally. It presents potential human health risks via direct exposure to heavy metals, as well as via indirect changes to the food chain because of the effects on soil microbiota, crops and livestock (Grimm et al., 2008). In China, pollution from heavy metals, particularly chromium and cadmium, had been widely reported in major rice production areas, including the lower Yangtze River delta (Wu et al., 2006; Hang et al., 2009) and the river valleys in the Jiangxi and Hubei Provinces (Xu et al., 2007). It is critical to reduce the bioavailability of heavy metals, and thus to prevent soil-food chain transfer of toxic metals from rice paddies (Chaney et al., 2004). Results presented here of DGGE and sequence data show that heavy metal contamination can strongly affect microbial community structure and abundance. DGGE showed that as heavy metal concentration and plant growth increased, the microbial community diversity and abundance decreased. Particular haplotypes were enriched in the contaminated samples, suggesting that particular individual species of heavy metal resistant bacteria may thrive in contaminated environments. The PCRDGGE method can provide detailed information about microbial community structure and how it changes with particular parameters such as pollution. These results will be applicable to the assessment and remediation of rice paddies contaminated by heavy metals.

\section{Acknowledgments}

This work was financially supported by the Hubei Science and Technology [Grant No. 2014BBB001] and the Hubei Collaborative Innovation Center for Grain Industry.

\section{References}

Akcay, H., Oguz, A., Karapire, C. 2003. Study of heavy metal pollution and speciation in Buyak Menderes and Gediz river sediments. Water Res., 37: 813-822. doi: 10.1016/S00431354(02)00392-5.

Chaney, R.L., Reeves, P.G., Ryan, J.A. 
2004. An improved understanding of soil Cd risk to humans and low cost methods to phytoextract $\mathrm{Cd}$ from contaminated soils to prevent soil $\mathrm{Cd}$ risks. Biometals, 17: 549-553.

Chen, J.H., He, F., Zhang, X.H., Sun, X., Zheng, J.F., Zheng, J.W. 2014. Heavy metal pollution decreases microbial abundance, diversity and activity within particle-size fractions of a paddy soil. FEMS Microbiol. Ecol., 87: 164-181. doi: 10.1111/15746941.12212

Daniela, R.D.F., Raquel, V.F., Mario, C., Teresa, C.D.M., Marrio, J.P., Bruno, B.C., Antonio, C. 2012. Impact of water quality on bacterioplanktonassemblage along certima river basin (central western Portugal) accessed by PCR-DGGE and multivariate analysis. Environ. Monit. Assess., 184: 471-485.

Eguchi, M., Ostrowski, M., Fegatella, F., Bowman, J., Nichols, D., Nishino, T., Cavicchioli, R. 2001. Sphingomonas alaskensis strain AFO1, an abundant oligotrophic ultramicrobacterium from the North Pacific. Appl. Environ. Microbiol., 67: 4945-4954. doi:10.1128/Aem.67. 11.49454954.2001

Frische, T., Hoper, H. 2003. Soil microbial parameters and luminescent bacteria assays as indicators for in situ bioremediation of TNT contaminated soils. Chemosphere, 50: 415-427. doi: 10.1016/S0045-6535(02)00603-3

Gong, J.L., Wang, B., Zeng, G.M., Yang, C.P., Niu, C.G., Niu, Q.Y., Zhou, W.J., Liang, Y. 2009. Removal of cationic dyes from aqueous solution using magnetic multi-wall carbon nanotube nanocomposite as adsorbent. J. Hazard. Mater., 164: 1517-1522. doi:10.1016/j.jhazmat.2008.09.072

Grimm, B.N., Foster, D., Groffman, P.,
Grove, M.J. 2008. The changing landscape: ecosystem responses to urbanization and pollution across climatic and societal gradients. Front Ecol. Environ., 6(5): 264-272.

Hamed, A., Maria, N., Ryszard, L., et al. 2015. Microbial community composition and functions are resilient to metal pollution along two forest soil gradients. FEMS Microbiol. Ecol., 91: $1-11$.

Hang, X., Wang, H., Zhou, J., Ma, C., Du, C. 2009. Risk assessment of potentially toxic element pollution in soils and rice (Oryza sativa) in a typical area of the Yangtze River Delta. Environ. Pollut., 157: 2542549.

Huang, J., Sheng, X., He, L., Huang, Z., Wang, Q., Zhang, Z. 2013. Characterization of depth-related changes in bacterial community compositions and functions of a paddy soil profile. FEMS Microbiol. Lett., 347(1): 33-42.

Hill, T.C.J., Walsh, K.A., Harris, J.A. 2003. Using ecological diversitymeasures with bacterial communities. FEMS Microbiol. Ecol., 43: 1-11.

Khan, S., Hesham, A.E.L., Qiao, M., Rehman, S., He, J.Z. 2010. Effects of $\mathrm{Cd}$ and $\mathrm{Pb}$ on soil microbial community structure and activities. Environ. Sci. Pollut. Res. Int., 17: 288-296. doi: 10.1007/s11356-0090134-4

Kumar, S. 2008. MEGA: a biologist-centric software for evolutionaryanalysis of DNA and protein sequences. Life Sci. Brief Bioinform, 9(4): 299-306.

Lucas-Borja, M.E., Candel, D., Jindo, K., Moreno, J.L., Andres, M., Bastida, F. 2012. Soil microbial community structure and activity in monospecific and mixed forest stands, under Mediterranean humid conditions. 
Plant Soil, 354: 359-370.

Lobinski, R., Boutron, C.F., Candelone, J.P,. Hong, S., Szpunar-Lobinska, J., Adams, F.C. 1994. Present century snow core record of organolead pollution in Greenland. Environ. Sci. Technol., 28: 1467-1471. doi:10.1021/es00057a014

Sabater, S., Buchaca, T., Cambra, J., Catalan, J., Guasch, H., Ivorra, N., Munoz, I., Navarro, E., Real, M., Romani, A. 2003. Structure and function of benthic algal communities in an extremely acid river. J. Phycol., 39: 481-489. doi: 10.1046/j.15298817.2003.02104.x

Tang, W.W., Zeng, G.M., Gong, J.L., Liang, J., Xu, P., Zhang, C., Huang, B.B. 2014. Impact of humic/fulvic acid on the removal of heavy metals from aqueous solutions using nanomaterials: A review. Sci. Total Environ., 468: 1014-1027. doi: 10.1016/j.scitotenv.2013.09.044

Tonkovic, Z. 1998. Energetics of enhanced biological phosphorus and nitrogen removal processes. Water Sci. Technol., 38: 177-184. doi: 10.1016/S0273-1223(98)00402-8

Van de Velde, K., Vallelonga, P., Candelone, J.P., Rosman, K.J.R., Gaspari, V., Cozzi, G., Barbante, C., Udisti, R., Cescon, P., Boutron, C.F. 2005. $\mathrm{Pb}$ isotope record over one century in snow from Victoria Land, Antarctica. Earth Planet Sci. Lett., 232: 95-108. doi: 10.1016/j. epsl.2005.01.007

Van Hannen, E.J., Zwart, G., van Agterveld, M.P., Gons, H.J., Ebert, J., Laanbroek, H.J. 1999. Changes in bacterial and eukaryotic community structure after mass lysis of filamentous cyanobacteria associated with virus. Appl. Environ. Microbiol., 65: 795801.

Wang, Y.P., Shi, J.Y., Wang, H., Lin, Q., Chen, X.C., Chen, Y.X. 2007. The influence of soil heavy metal pollution on soil microbial biomass, enzyme activity, and community composition near a copper smelter. Ecotox. Environ. Safe, 67: 75-81. doi: 10.1016/j.ecoenv.2006.03.007

Wu, X., Pan, G., Li, L. 2006. Study on soil quality change in the Yangtze River Delta. Geogra Geo Inf. Sci., 22: 8891.

Xu, P., Zeng, G.M., Huang, D.L., Feng, C.L., Hu, S., Zhao, M.H., Lai, C., Wei, Z., Huang, C., Xie, G.X., Liu, Z.F. 2012. Use of iron oxide nanomaterials in wastewater treatment: a review. Sci. Total Environ., 424: 1-10. doi: 10. 1016/j.scitotenv.2012.02.023

Xu, C., Xia, B., Qin, J., He, S., Li, H. 2007. Analysis and evaluation on heavy metal contamination in paddy soils in the lower stream of Dabaoshan Area, Guangdong Province. J. AgroEnviron. Sci., 26: 549-553.

Zeng, G.M., Chen, M., Zeng, Z.T. 2013a. Risks of neonicotinoid pesticides. Sci., 340: 1403-1403.

\section{How to cite this article:}

Ding Zili, Wu Jinping, Jiao Chunhai, Cao Cougui. 2016. Analysis of Bacterial Community in the Rhizosphere of Rice subjected to Heavy Metal Pollution. Int.J.Curr.Microbiol.App.Sci. 5(9): 816-825. doi: http://dx.doi.org/10.20546/ijcmas.2016.509.092 